\title{
Paleosols in the Transantarctic Mountains: indicators of environmental change
}

\author{
J. G. Bockheim \\ Department of Soil Science, University of Wisconsin, Madison, WI 53706-1299, USA \\ Correspondence to: J. G. Bockheim (bockheim@wisc.edu) \\ Received: 6 June 2013 - Published in Solid Earth Discuss.: 17 July 2013 \\ Revised: 11 September 2013 - Accepted: 16 September 2013 - Published: 20 November 2013
}

\begin{abstract}
The Transantarctic Mountains (TAMs), a $3500 \mathrm{~km}$ long chain that subdivides East Antarctica from West Antarctica, are important for reconstructing the tectonic, glacial, and climatic history of Antarctica. With an ice-free area of $24200 \mathrm{~km}^{2}$ (50\% of the total in Antarctica), the TAMs contain an unusually high proportion of paleosols, including relict and buried soils. The unconsolidated paleosols range from late Quaternary to Miocene in age, the semiconsolidated paleosols are of early Miocene to Oligocene age, and the consolidated paleosols are of Paleozoic age. Paleosols on unconsolidated deposits are emphasized in this study. Examples are given from the McMurdo Dry Valleys $\left(78^{\circ} \mathrm{S}\right)$ and two outlet glaciers in the central and southern TAMS, including the Hatherton-Darwin Glacier region $\left(80^{\circ} \mathrm{S}\right)$ and the Beardmore Glacier region $\left(85^{\circ} 30^{\prime} \mathrm{S}\right)$. Relict soils constitute $73 \%$ of all of the soils examined; $10 \%$ of the soils featured burials. About $26 \%$ of the soils examined are from the last glaciation $(<117 \mathrm{ka})$ and have not undergone any apparent change in climate. As an example, paleosols comprise $65 \%$ of a mapped portion of central Wright Valley. Paleosols in the TAMs feature recycled ventifacts and buried glacial ice in excess of $8 \mathrm{Ma}$ in age, and volcanic ash of Pliocene to Miocene age has buried some soils. Relict soils are more strongly developed than nearby modern soils and often are dry-frozen and feature sand-wedge casts when ice-cemented permafrost is present. The preservation of paleosols in the TAMs can be attributed to cold-based glaciers that are able to override landscapes while causing minimal disturbance.
\end{abstract}

\section{Introduction}

In the soils literature, paleosols refer to buried, relict and exhumed soils with no assigned age (Ruhe, 1965; Nettleton et al., 2000) or to soils in which the chemical and physical characteristics are unrelated to the present-day climate or vegetation (Bronger and Catt, 1989). Many soils of ice-free areas of Antarctica, predominantly in the Transantarctic Mountains (TAMs), have been exposed to subaerial weathering since the early Quaternary to the Miocene (Campbell and Claridge, 1987; Bockheim, 1990; Hall et al., 1993; Prentice et al., 1993; Bockheim, 2007), and buried soils have been commonly reported (Bockheim, 1982; Bockheim et al., 1989). This study addresses the properties, distribution, and interpretation of paleosols in the TAMs.

The TAMs extend more than $3500 \mathrm{~km}$ from North Victoria Land to the tip of the Antarctic Peninsula (Fig. 1) and reach elevations of over $4500 \mathrm{~m}$. The TAMs contain about $50 \%$, or $24000 \mathrm{~km}^{2}$, of the ice-free area of Antarctica, form a natural barrier between ice in East and West Antarctica, and record the history of Cenozoic glaciations of Antarctica (Mercer, 1968; Denton et al., 1989; Bockheim et al., 1989). Valleys within the TAMs have been cut by major outlet glaciers that today are buttressed by the Ross Ice Shelf. These include, but are not restricted to, the Darwin-Byrd, Beardmore, Shackleton, Scott, and Reedy glaciers. Each of these outlet glaciers contains a chronosequence of soils that ranges from the late Quaternary to the Pliocene or Miocene in age and features relict and buried soils (Bockheim, 1990).

Previous investigations in Antarctica have examined lithified paleosols of late Paleozoic to early Triassic age (Retallack and Alonso-Zarza, 1998) and well-known exposures of semi-lithified paleosols of Miocene age (Retallack et al., 


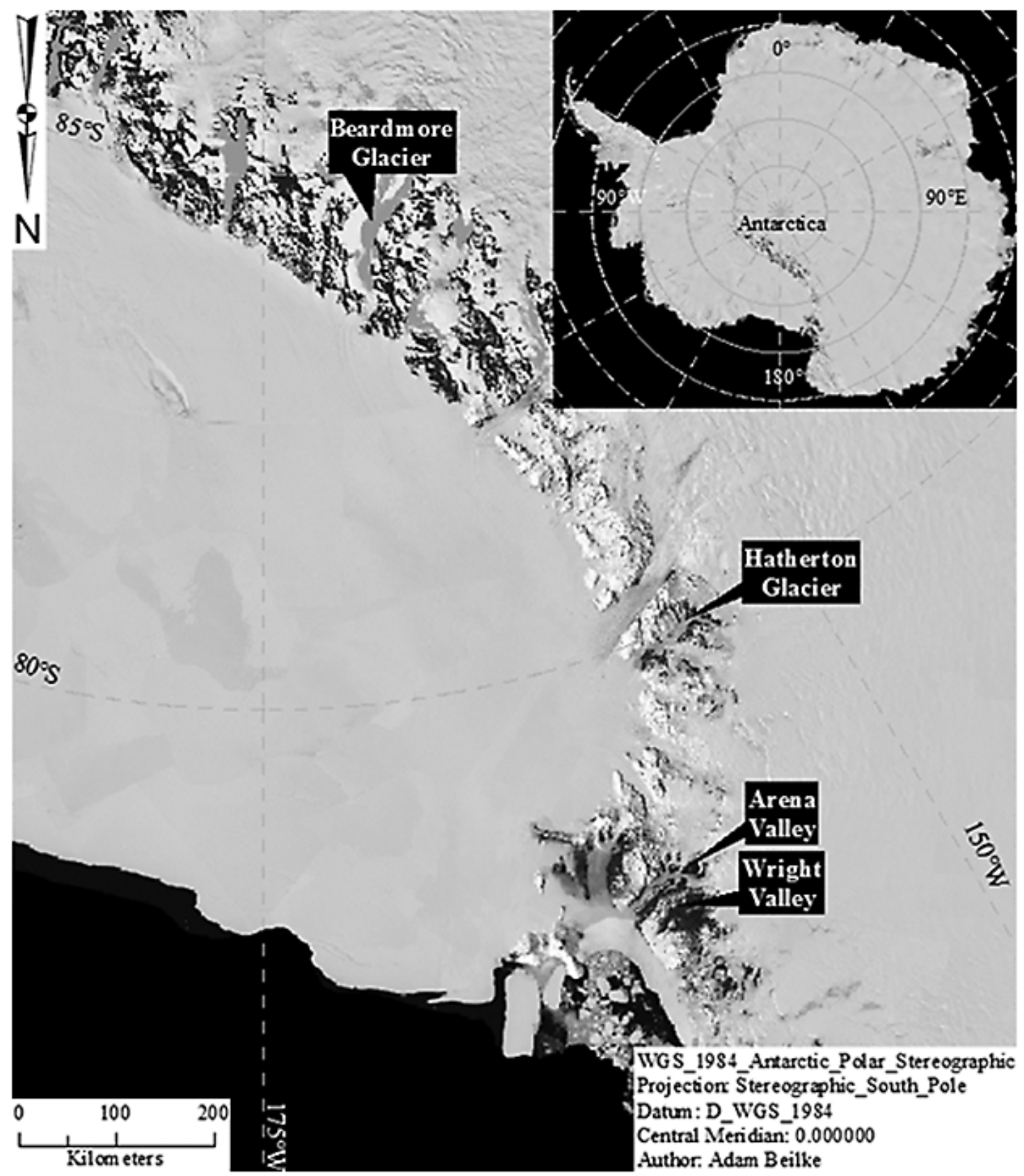

Fig. 1. Study areas in the Transantarctic Mountains.

2002; Mahaney et al., 2001, 2012). Relict soils along the edge of the polar plateau throughout the TAMs have properties resulting from hyper-arid conditions, suggesting that the climate has remained cold and dry since the Miocene (Marchant et al., 1994).

\section{Study areas}

The University of Wisconsin Antarctic Soils (http: //nsidc.org/data/ggd221.html) and New Zealand Land- care Research (http://www.landcareresearch.co.nz/science/ soils-and-landscapes/antarctic-soils) databases were used in this study. The databases contain information about surface boulder weathering features and soils from some of more than 800 sites in the Transantarctic Mountains from North Victoria Land and South Victoria Land, with an emphasis on the McMurdo Dry Valleys (Fig. 1). For this study, seven chronosequences were selected from the TAMs, including those in Wright Valley from alpine glaciers and from grounding of ice in the Ross embayment, and 
sequences from outlet glaciers from the East Antarctic ice sheet, including the Taylor Glacier (Arena Valley, Beacon Valley, and Taylor Valley), the Hatherton-Darwin Glacier, and the Beardmore Glacier. The chronosequences were selected on the basis of having a long time interval, the availability of numerical ages, and uniformity in parent material composition of member soils (Table 1). Individual sampling sites were selected on key moraines representing a particular glacial advance. Table 2 provides a provisional correlation of glacial deposits in the TAMs.

The composition of the drifts can be grouped into two broad categories. Mixed, light-colored igneous (granites) and metamorphic (gneisses) materials dominate the three sequences in Wright and Taylor Valleys. The sequences in Arena and Beacon Valleys and the Hatherton and Beardmore Glacier regions are comprised of Beacon Sandstone and Ferrar Dolerite (Table 1). Locally, some of the drifts may contain primarily dark-colored volcanic materials or diabase dike rocks. All age categories have samples from both rock types except that they lack Miocene-aged soils derived from granite-gneiss.

The chronosequences represent the three microclimatic zones identified in the Transantarctic Mountains by Marchant and Head (2007), including a coastal thaw zone, an inland mixed zone, and a stable upland zone. The zones are defined on the basis of summertime measurements of atmospheric temperature, soil moisture, and relative humidity. Subtle variations in these climate parameters result in considerable differences in the distribution and morphology of: (1) macroscale features (e.g., slopes and gullies); (2) mesoscale features (e.g., polygons, including icewedge, sand-wedge, and sublimation-type polygons, as well as viscous-flow features, including gelifluction lobes and debris-covered glaciers); (3) microscale features (e.g., rockweathering processes/features, including salt weathering, wind erosion, and surface pitting); and, hence, soil development.

The approximate mean annual water-equivalent precipitation in these zones is $100-50 \mathrm{~mm} \mathrm{yr}^{-1}, 50-10 \mathrm{~mm} \mathrm{yr}^{-1}$, and $<10 \mathrm{~mm} \mathrm{yr}^{-1}$, respectively. Most of the soil chronosequences span one soil climatic zone. However, the sequences in lower Wright Valley and along the Hatherton and Beardmore Glaciers span two soil climate zones, because their distance from the coast ranges from 35 to $220 \mathrm{~km}$. The chronosequences range in elevation from 200 to $2200 \mathrm{~m}$ a.s.l. and span the time period from Holocene or late Quaternary to the Pliocene and/or the Miocene (Table 1).

\section{Methods and materials}

\subsection{Field}

Methods used in this study were described in detail by Bockheim $(2010 a, b)$ and will only be highlighted here. Soil pits were excavated to a depth of at least $100 \mathrm{~cm}$, unless icecement or large boulders prevented digging to that depth. Detailed soil descriptions were taken using standard techniques (Schoeneberger et al., 2002). Samples were collected from each horizon and sent to the United States for characterization.

Several soil morphological features, which have proven useful for distinguishing among drift sheets in TAMs (Bockheim, 2010b), were measured in the field. The depth of staining refers to the thickness of the layers showing the strongest hues and chromas from oxidation of iron-bearing minerals and corresponds to the bottom of the Bw horizon. The depth of coherence refers to the thickness of consolidated soil from accumulation of weathering products such as salts and iron oxide; below the depth of coherence, soil readily caves into the pit. The depth of "ghosts" (pseudomorphs) refers to the depth to which highly weathered clasts were observed in situ; this parameter varies with rock type as well as soil age. The depth of visible salts refers to the maximum depth for which salt encrustations beneath clasts, salt flecks, and salt cementation are readily visible to the naked eye.

Bockheim (1990) developed a six-stage sequence in which the form of soluble salts was related to total dissolved salts from electrical conductivity (EC) measurements and soil age: $0=$ no visible salts, $1=$ salt encrustations beneath clasts, $2=$ salt flecks covering $<20 \%$ of the horizon area, $3=$ salt flecks covering $>20 \%$ of the horizon area, $4=$ weakly cemented salt pan, $5=$ strongly cemented salt pan, and $6=$ indurated salt pan. The depth to ice or ice-cemented permafrost was determined. The active layer (seasonal thaw layer) in the Transantarctic Mountains varies from 15 to $60 \mathrm{~cm}$. Material not cemented by ice beneath the active layer may contain "dry-frozen" permafrost, i.e. perennially frozen materials lacking sufficient interstitial water to cause cementation.

The weathering stage is an overall representation of the landscape/material based on the degree of surface boulder weathering, soil morphology, and patterned ground and permafrost forms (Bockheim, 2010b). The stages are: $1=$ unstained angular boulders, no horizonation $(\mathrm{Cn})$, stage 0 or 1 salts, ice cement within $70 \mathrm{~cm}$ of surface, and patterned; $2=$ lightly stained subangular boulders, weak horizonation (Cox), stage 2 salts, may have ice cement, patterned ground; $3=$ distinct polish and rounding of boulders, some cavernous weathering, distinct horizonation (Bw), stage 3 salts, moderately deep profile; $4=$ strongly developed cavernous weathering, ventifaction, very distinct horizonation, stage 4 salts, deep profile; $5=$ low surface boulder frequency, well developed desert pavement, very distinct horizonation, stage 5 salts, deep profile; and $6=$ low surface boulder frequency, well developed desert pavement, macro-pits in dolerite, very distinct horizonation, stage 6 salts, shallow to deep profile with bedrock possibly occurring in the lower solum.

Buried soils were easily identified from marked changes with depth in staining, salt morphology, ghosts, and other 
Table 1. Site factors of soil chronosequences in the Transantarctic Mountains.

\begin{tabular}{|c|c|c|c|c|c|c|c|c|c|}
\hline \multirow[t]{2}{*}{ Area } & \multirow{2}{*}{$\begin{array}{l}\text { Total No. } \\
\text { pedons }\end{array}$} & \multirow[t]{2}{*}{ Glaciation } & \multirow[t]{2}{*}{ Drifts $^{a}$} & \multirow{2}{*}{$\begin{array}{l}\text { Age } \\
\text { span }\end{array}$} & \multirow{2}{*}{$\begin{array}{l}\text { Drift } \\
\text { composition }\end{array}$} & \multirow{2}{*}{$\begin{array}{l}\text { Soil climatic } \\
\text { zone }^{\mathrm{b}}\end{array}$} & \multirow{2}{*}{$\begin{array}{l}\text { Elevation } \\
\text { range }(\mathrm{m})\end{array}$} & \multicolumn{2}{|c|}{ References } \\
\hline & & & & & & & & Soils & Parent material \\
\hline Wright Valley & 58 & alpine & $\mathrm{A} 1, \mathrm{~A} 2, \mathrm{~A} 3, \mathrm{~A} 4$ & $.7 \mathrm{ka}$ to $>3.7 \mathrm{Ma}$ & granitic-gneiss & mixed & $250-950$ & $\begin{array}{l}\text { Bockheim and } \\
\text { McLeod (2006) }\end{array}$ & $\begin{array}{l}\text { Hall et al. (1993), } \\
\text { Hall and Denton (2005) }\end{array}$ \\
\hline Arena Valley & 54 & Taylor & $\begin{array}{l}\text { T2, T3, T4a, T4b, } \\
\mathrm{Ar}, \mathrm{Al}, \mathrm{Q}\end{array}$ & $117 \mathrm{ka}$ to $>15 \mathrm{Ma}$ & dolerite-sandstone & stable upland & $900-1500$ & Bockheim (2007) & Marchant et al. (1993a) \\
\hline Beaco & 20 & Taylor & $\mathrm{T} 2, \mathrm{~T} 3, \mathrm{~T} 4, \mathrm{Al}$ & $17 \mathrm{ka}-15 \mathrm{Ma}$ & dstone & stable & $800-1350$ & Bockh & Bockheim (2007) \\
\hline Taylor Valley & 64 & Taylor & $\mathrm{T} 2, \mathrm{~T} 3, \mathrm{~T} 4 \mathrm{a}, \mathrm{T} 4 \mathrm{~b}$ & $117 \mathrm{ka}-2.7 / 3.5 \mathrm{Ma}$ & granitic-gneiss & inland mixed & $200-1350$ & Bockheim et al. (2008) & Wilch et al. (1993) \\
\hline Wright Valley & 42 & $\begin{array}{l}\text { Wilson } \\
\text { Piedmont }\end{array}$ & $\begin{array}{l}\text { B, H1, L, H2, T, } \\
\text { O, W, V, Lp }\end{array}$ & $3.7 \mathrm{ka}$ to $>2 \mathrm{Ma}$ & granitic-gneiss & $\begin{array}{l}\text { coastal thaw, } \\
\text { inland mixed }\end{array}$ & $275-350$ & $\begin{array}{l}\text { Bockheim and } \\
\text { McLeod (2006) }\end{array}$ & Hall and Denton (2005) \\
\hline $\begin{array}{l}\text { Hatherton } \\
\text { Glacier }\end{array}$ & 53 & Hatherton & $\begin{array}{l}\mathrm{Ha}, \mathrm{Br} 1, \mathrm{Br} 2, \mathrm{D} \text {, } \\
\text { I, pre-I }\end{array}$ & $8 \mathrm{ka}$ to $>600 \mathrm{ka}$ & dolerite-sandstone & $\begin{array}{l}\text { inland mixed, } \\
\text { stable upland }\end{array}$ & $1000-2200$ & Bockheim et al. (1989) & Bockheim et al. (1989) \\
\hline $\begin{array}{l}\text { Beardmore } \\
\text { Glacier }\end{array}$ & 38 & Beardmore & $\begin{array}{l}\mathrm{Pl}, \mathrm{Be}, \mathrm{M}, \text { pre-M, } \\
\mathrm{D}, \mathrm{S}\end{array}$ & $14 \mathrm{ka}-2 \mathrm{Ma}$ & diorite-sandstone & $\begin{array}{l}\text { inland mixed, } \\
\text { stable upland }\end{array}$ & & Bockheim (1990) & $\begin{array}{l}\text { Denton et al. (1989), } \\
\text { Ackert and Kurz (2004) }\end{array}$ \\
\hline
\end{tabular}

a Drift names: A = Alpine; $\mathrm{Al}=\mathrm{Altar} ; \mathrm{Ar}=$ Arena; $\mathrm{B}=$ Brownworth; $\mathrm{Be}=$ Beardmore; $\mathrm{Br}=\mathrm{Britannia} ; \mathrm{D}=\mathrm{Danum} ; \mathrm{H}=\mathrm{Hummocky} ; \mathrm{Ha}=\mathrm{Hatherton} ; \mathrm{I}=\mathrm{Isca} ; \mathrm{L}=\mathrm{Loke} ; \mathrm{Lp}=\mathrm{Loop}$; $\mathrm{P}=$ Peleus; $\mathrm{Pl}=$ Plunket; $\mathrm{O}=$ Onyx; $\mathrm{Q}=$ Quartermain; $\mathrm{S}=$ Sirius; $\mathrm{T}=$ Trilogy; V = Valkyrie; $\mathrm{W}=$ Wright.

b Soil climate zones after Marchant and Head (2007).

Table 2. Provisional correlation of glacial deposits* in the Transantarctic Mountains.

\begin{tabular}{|c|c|c|c|c|c|c|c|c|}
\hline $\begin{array}{l}\text { Geologic } \\
\text { time scale }\end{array}$ & $\begin{array}{l}\text { Taylor V. } \\
\text { Taylor Gl. }\end{array}$ & $\begin{array}{l}\text { Wright V. } \\
\text { Alpine }\end{array}$ & $\begin{array}{l}\text { Wright V. } \\
\text { Wilson } \\
\text { Pied. Gl. }\end{array}$ & $\begin{array}{l}\text { Arena V. } \\
\text { Taylor Gl. }\end{array}$ & $\begin{array}{l}\text { Beacon V. } \\
\text { Taylor Gl. }\end{array}$ & $\begin{array}{l}\text { Hatherton } \\
\text { Glacier }\end{array}$ & $\begin{array}{l}\text { Beardmore } \\
\text { Glacier }\end{array}$ & $\begin{array}{l}\text { Numerical } \\
\text { Dating }\end{array}$ \\
\hline Holocene & & A1 & & & & Hatherton & $\mathrm{Pl}$ & $3.7 \mathrm{Ky}$ \\
\hline \multirow{4}{*}{ late Quaternary } & & & B & & & $\mathrm{Br} 1, \mathrm{Br} 2$ & $\mathrm{Be}$ & $10 \mathrm{Ky}$ \\
\hline & $\mathrm{T} 2$ & $\mathrm{~A} 2 \mathrm{a}$ & & $\mathrm{T} 2$ & $\mathrm{~T} 2$ & & & $117 \mathrm{Ky}$ \\
\hline & & & H1 & & & $\mathrm{D}$ & M & \\
\hline & $\mathrm{T} 3$ & $\mathrm{~A} 2 \mathrm{~b}$ & & $\mathrm{~T} 3$ & $\mathrm{~T} 3$ & & & $200 \mathrm{Ky}$ \\
\hline middle Quaternary & & & $\begin{array}{l}\text { Loke, } \mathrm{H} 2 \\
\mathrm{~T}\end{array}$ & & & I & pre-M & \\
\hline \multirow[t]{2}{*}{ early Quaternary } & $\mathrm{T} 4 \mathrm{a}$ & & & $\mathrm{T} 4 \mathrm{a}$ & $\mathrm{T} 4 \mathrm{a}$ & & & $1.0-1.1 \mathrm{My}$ \\
\hline & $\mathrm{T} 4 \mathrm{~b}$ & & & $\mathrm{~T} 4 \mathrm{~b}$ & $\mathrm{~T} 4 \mathrm{~b}$ & & & $1.1-2.2 \mathrm{My}$ \\
\hline \multirow[t]{5}{*}{ Pliocene } & & & $\mathrm{O}, \mathrm{W}$ & & & pre-I & Do & $<3.4 \mathrm{My}$ \\
\hline & & A3 & & & & & & $<3.5 \mathrm{My}$ \\
\hline & & & $\mathrm{V}$ & & & & & \\
\hline & & A4 & & & & & & $>3.7 \mathrm{My}$ \\
\hline & & & $\begin{array}{l}\text { Lp } \\
\text { P }\end{array}$ & & & & & \\
\hline \multirow[t]{2}{*}{ Miocene } & & & & & & & $S$ & 7.7 My \\
\hline & & & & $\mathrm{Al}, \mathrm{Ar}$ & $\mathrm{Al}$ & & & $>11.3 \mathrm{My}$ \\
\hline References & $\begin{array}{l}\text { Brook et al. } \\
\text { (1993), Wilch } \\
\text { et al. (1993), } \\
\text { Higgins et al. } \\
(2000)\end{array}$ & $\begin{array}{l}\text { Hall and } \\
\text { Denton } \\
(2005)\end{array}$ & $\begin{array}{l}\text { Hall and } \\
\text { Denton } \\
(2005)\end{array}$ & $\begin{array}{l}\text { Marchant } \\
\text { et al. } \\
(1993 a)\end{array}$ & $\begin{array}{l}\text { Bockheim } \\
\text { (2007) }\end{array}$ & $\begin{array}{l}\text { Bockheim } \\
\text { et al. (1989) }\end{array}$ & $\begin{array}{l}\text { Denton et al. } \\
(1989), \\
\text { Ackert and } \\
\text { Kurz (2004) }\end{array}$ & \\
\hline
\end{tabular}

* Drift names: A = Alpine; $\mathrm{Al}=$ Altar; $\mathrm{Ar}=$ Arena $\mathrm{B}=$ Brownworth $; \mathrm{Be}=$ Beardmore; $\mathrm{Br}=\mathrm{Britannia} ; \mathrm{D}=\mathrm{Danum} ; \mathrm{Do}=\mathrm{Dominion} ; \mathrm{H}=\mathrm{Hummocky} ; \mathrm{Ha}=\mathrm{Hatherton} ; \mathrm{I}=\mathrm{Isca}$; $\mathrm{L}=$ Loke; Lp = Loop; $\mathrm{M}=$ Meyer; $\mathrm{P}=$ Peleus; $\mathrm{Pl}=$ Plunket; $\mathrm{O}=$ Onyx; $\mathrm{Q}=$ Quartermain; $\mathrm{S}=$ Sirius; $\mathrm{T}=$ Trilogy; $\mathrm{V}=$ Valkyrie; $\mathrm{W}=\mathrm{Wright}$.

weathering features. Buried soils occasionally contain a desert pavement with intact ventifacts; and burial generally was caused by glacier overriding but also by lava flows, volcanic ash deposition, and colluviation. Relict soils were distinguished from their relative age or assigned glacial deposit (Table 1) and from their degree of development when compared to soils on the most recent glacial deposits in the area. For this study all soils on glacial deposits older than $117 \mathrm{ka}$ were considered to be relict (Table 2). However, many of the non-relict soils ranged from $<10$ to $24 \mathrm{ka}$ in age.
Soils were classified into the Gelisol order to the family level (Soil Survey Staff, 2010); mineral soils showing cryoturbation are classified as Turbels; mineral soils without obvious cryoturbation are Orthels. Both suborders are divided into great groups on the basis of soil climate and other soil properties. Many soils of the Transantarctic Mountains have anhydrous conditions (i.e. the mean annual precipitation is less than $50 \mathrm{~mm}$ water equivalent) and are classified into the great groups, Anhyturbels or Anhyorthels. Equivalent soils with greater moisture contents are classified into the great 
groups, Haploturbels or Haplorthels. The soils are further divided into subgroups on the basis of presence of soluble salts (e.g. salic, gypsic, nitric, petrogypsic, and petronitric), depth to bedrock (lithic), or other (typic) soils.

Bockheim and McLeod (2013) developed a multipleparameter, relative chronology of the TAMs based on the parameters previously described. Normally, the surface-boulder weathering and soil weathering values are similar. However, in the case of overriding by cold-based glaciers, boulder-belt moraines or scattered boulders may be left on the landscape, creating buried or relict soils.

\subsection{Laboratory}

Electrical conductivity, $\mathrm{pH}$, and dominant cations and anions were determined on $1: 5$ soil : distilled water extracts using a conductivity bridge and cell, $\mathrm{pH}$ meter, and atomic absorption spectroscopy (APHA et al., 1975). Particle-size distribution was done with the hydrometer method (Day, 1965); Fe was extracted using the citrate-dithionite-carbonate procedure (Mehra and Jackson 1960).

\section{Results}

Of the 763 soils examined in TAMs, $10 \%$ contained burials and $73 \%$ were relict (Table 3 ). Only $26 \%$ of the soils did not contain burials or occurred on deposits from the most recent glaciations, considered to be $<117 \mathrm{ka}$.

\subsection{Evidence for burial}

Burial was evidenced primarily from lithologic discontinuities, marked changes in soil horizonation and properties, and relict cryoturbation or periglacial features. In the TAMs, drift from wet-based glaciers of Pliocene and older age is enriched in quartz of silt and very-fine sand size $(100-2 \mu \mathrm{m})$ with few clasts, primarily from overriding outcrops of the Beacon Supergroup. These materials are whitish in color and are resistant to weathering. In contrast, drifts from cold-based glaciers have a sandy matrix and abundant coarse fragments $(>2 \mathrm{~mm})$ and contain iron-rich minerals that provide a distinctive reddish color (5-7.5 yr) upon weathering. Deposits of Miocene-age from wet-based glaciers include the Sirius Group at high elevations throughout the TAMs, Altar and Quartermain drifts in Arena Valley (Marchant et al., 1993a), Asgard and Sessrumnir drifts in the Asgard Range (Marchant et al.,1993b), Insel drift in Victoria Valley (Calkins, 1971), and Peleus drift in Wright Valley (Hall et al., 1993; Prentice et al., 1994). These materials may have been buried by drift from cold-based glaciers (Fig. 2a) or reworked into the drift of cold-based glaciers (Fig. 2b). Pliocene- or Miocene-aged volcanic ash (Fig. 2c), and lava flows (Fig. 2d) may also bury soils.

Eolian events that lead to coarse gravelly mega-ripples (Gillies et al., 2012) may have reworked the upper parts of

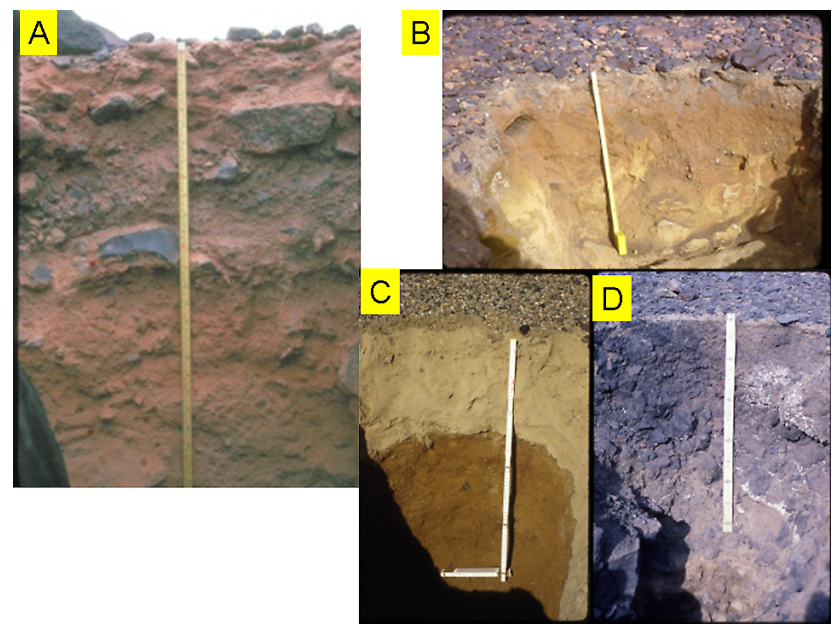

Fig. 2. Examples of buried soils in the Transantarctic Mountains: (A) this soil in upper Arena Valley shows multiple burials including scattered Taylor III boulders of $200 \mathrm{ka}$ age on the surface (not visible from image) over Taylor IV drift of early Pleistocene or late Pliocene age (the upper soil), which then buries Quartermain drift of Miocene age (notice the buried desert pavement including the intact ventifact on top of the buried Quartermain soil) (pedon 75-19); (B) a soil derived from early Pleistocene-aged drift containing pieces of formerly frozen Pliocene-aged drift in the Darwin Mountains (pedon 78-33); (C) the 3.9 Ma Hart ash burying a strongly developed soil from colluvium in central Wright Valley (pedon 87-29); (D) a lava flow burying an intensively developed soil in Taylor Valley containing abundant salts (pedon 84-05). K-Ar dating of lava flows can provide limiting ages of buried soils.

soils (Fig. 3a); although these events do not constitute burials, they likely reflect a change in climate. Changes in levels of Lake Vanda from climate change have produced strandlines below which buried soils occur (Fig. 3b).

Soil horizonation also provides clues of burials in the TAMs. Approximately $82 \%$ of the 80 burials observed in the Transantarctic Mountains featured readily distinguishable buried B horizons (Fig. 3c). The key soil properties for identifying buried soils include sudden changes in depth in color, salt content or stage, ghosts, cohesion, and the appearance of buried in situ ventifacts.

Morphological evidence for burial often is corroborated by laboratory data. Pedon 75-19 shows dramatic increases in $\mathrm{Na}, \mathrm{Cl}, \mathrm{SO}_{4}, \mathrm{Fe}_{\mathrm{d}}$, silt and clay from the Taylor IV relict soil to the buried soil derived from Miocene-aged drift (Table 4; see also Fig. 2a).

\subsection{Evidence for relict soils}

Relict soils are predominant in ice-free areas of the TAMs. These soils commonly have abundant salts, are deeply weathered, contrast with soils on younger glacial deposits nearby, or have remained undisturbed for long periods of time (Fig. 4a). 
Table 3. Distribution of buried, relict, and modern soils in the Transantarctic Mountains by area and type of glacier ${ }^{\mathrm{a}}$.

\begin{tabular}{|c|c|c|c|c|c|c|c|c|}
\hline \multirow[b]{2}{*}{ Area } & \multirow[b]{2}{*}{ Type of glacier } & \multicolumn{4}{|c|}{ Number } & \multicolumn{3}{|c|}{$\%$} \\
\hline & & Buried & Relict & Modern $^{\mathrm{b}}$ & Total & Buried & Relict & Modern \\
\hline Arena Valley & outlet & 12 & 45 & 13 & 70 & 17 & 64 & 19 \\
\hline Arena Valley & overriding & 2 & 15 & 0 & 17 & 12 & 88 & 0 \\
\hline Asgard Range & overriding & 2 & 23 & 0 & 25 & 8 & 92 & 0 \\
\hline Beacon Valley & overriding & 0 & 11 & 0 & 11 & 0 & 100 & 0 \\
\hline Beacon Valley & outlet & 1 & 11 & 5 & 17 & 6 & 65 & 29 \\
\hline Beardmore Glacier & outlet & 7 & 35 & 29 & 71 & 10 & 49 & 41 \\
\hline Beardmore Glacier & overriding & 5 & 25 & 0 & 30 & 17 & 83 & 0 \\
\hline Beardmore Glacier & (not glacial) & 0 & 0 & 2 & 2 & 0 & 0 & 100 \\
\hline Darwin Glacier & outlet & 14 & 50 & 15 & 79 & 18 & 63 & 19 \\
\hline Ellsworth Mtns. & alpine & 1 & 2 & 19 & 22 & 5 & 9 & 86 \\
\hline North Victoria Land & outlet & 0 & 3 & 10 & 13 & 0 & 23 & 77 \\
\hline Royal Society Range & grounding & 0 & 15 & 4 & 19 & 0 & 79 & 21 \\
\hline Taylor Valley & alpine & 0 & 14 & 37 & 51 & 0 & 27 & 73 \\
\hline Taylor Valley & outlet & 8 & 90 & 18 & 116 & 7 & 78 & 16 \\
\hline Wright Valley & grounding & 3 & 70 & 19 & 92 & 3 & 76 & 21 \\
\hline Wright Valley & (not glacial) & 8 & 57 & 4 & 69 & 12 & 83 & 6 \\
\hline Wright Valley & alpine & 17 & 72 & 20 & 109 & 16 & 66 & 18 \\
\hline Wright Valley & overriding & 4 & 20 & 0 & 24 & 17 & 83 & 0 \\
\hline
\end{tabular}

a Note: some pedons are relict but also have burials.

${ }^{\mathrm{b}}$ Modern is assumed to be since the last glaciation, which is $<17 \mathrm{ka}$.

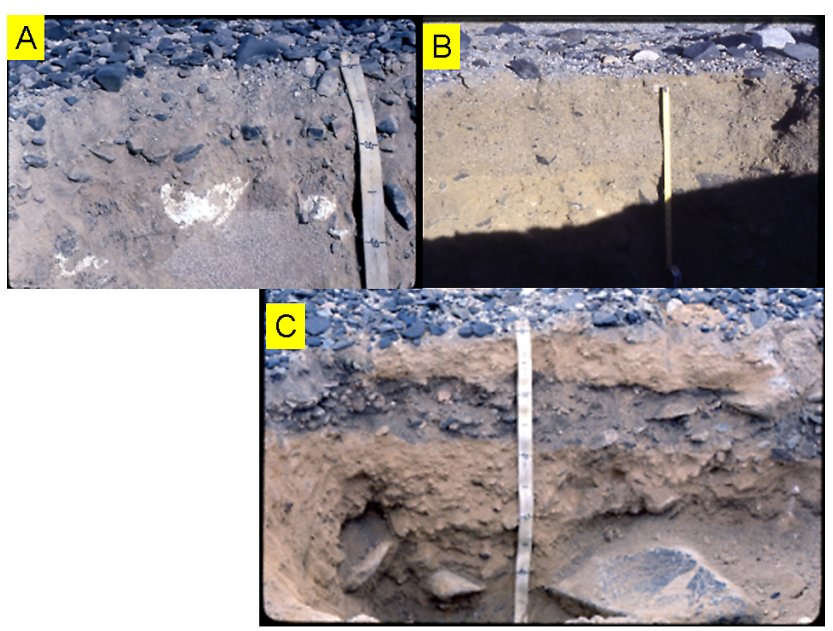

Fig. 3. Further examples of burial soils in the Transantarctic Mountains: (A) a mega-ripple of unknown age that has developed down to the salt pan of a soil developed on Alpine IIIb drift on the west side of the Conrow Glacier, central Wright Valley (pedon 83-41); (B) the upper strandline at Lake Vanda in upper Wright Valley showing lacustrine material burying a strongly developed soil of possible Pliocene age (pedon 77-28); (C) a soil derived from Alpine IIIa drift in Wright Valley that buries an intensely developed soil of Alpine IIIb or Alpine IV age (pedon 83-38).

Relict periglacial features are common in the TAMs, including former cryoturbation (Fig. 4b) and sand-wedge casts (Fig. 4c). These soils no longer have ice-cemented per-

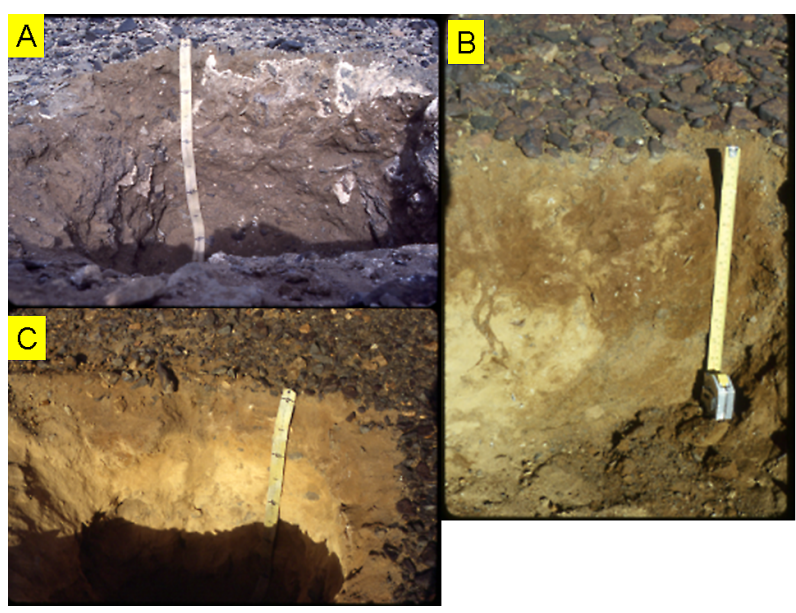

Fig. 4. Relict soils and features in the Transantarctic Mountains: (A) one of the most strongly developed soils we have observed in the Transantarctic Mountains, this soil is derived from Alpine IV drift in central Wright Valley, contains stage 6 salts, and is likely of Pliocene age (pedon 84-47); (B) cryoturbation in a soil now containing dry permafrost in the Labyrinth, upper Wright Valley (pedon 79-08); (C) a fossil sand wedge that passed through a soil derived from Taylor IV drift (Pliocene) and into a soil derived from Altar drift (Miocene) in upper Arena Valley (pedon 87-34).

mafrost in the upper $1 \mathrm{~m}$ to sustain these processes; rather, they contain dry-frozen permafrost from depths of 0.2 to $1 \mathrm{~m}$ or more from a progressive loss in soil moisture following the onset of hyper-arid conditions. 
Table 4. Laboratory data for buried soils in the Transantarctic Mountains.

\begin{tabular}{|c|c|c|c|c|c|c|c|c|c|c|c|c|c|c|c|c|c|}
\hline \multirow[b]{2}{*}{ Horizon } & \multirow{2}{*}{$\begin{array}{r}\text { Depth } \\
(\mathrm{cm})\end{array}$} & \multirow{2}{*}{$\begin{array}{r}\mathrm{EC} \\
\left(\mathrm{dS} \mathrm{m}^{-1}\right)\end{array}$} & \multirow[b]{2}{*}{$\mathrm{pH}$} & $\mathrm{Na}^{+}$ & $\mathrm{Ca}^{2+}$ & $\mathrm{Mg}^{2+}$ & $\mathrm{K}^{+}$ & $\mathrm{Cl}^{-}$ & $\mathrm{S}_{4}^{2-}$ & $\mathrm{NO}_{3}^{-}$ & Fed & Sand & Silt & Clay & Moist. & $\mathrm{Cl} / \mathrm{SO}_{4}$ & $\mathrm{Cl} / \mathrm{NO}_{3}$ \\
\hline & & & & \multicolumn{7}{|c|}{$\mathrm{mmol}_{\mathrm{c}} \mathrm{L}^{-1}$} & \multicolumn{7}{|c|}{$(\%)$} \\
\hline \multicolumn{18}{|c|}{ 75-19 Typic Anhyorthels, Taylor III/Taylor IV/Quartermain; Arena Valley } \\
\hline D & $0-1$ & 0.06 & 5.5 & 7.6 & 0.2 & 0.2 & 0 & 0 & 6.2 & 1.7 & 0.15 & 99.2 & 0.5 & 0.3 & & 0.000 & 0.00 \\
\hline $\mathrm{Bw}$ & $1-14$ & 1.43 & 6.4 & 143 & 0.7 & 1.1 & 0.1 & 0.1 & 144 & 0.6 & 0.22 & 93.6 & 2.7 & 3.7 & & 0.001 & 0.17 \\
\hline $\mathrm{BC}$ & $14-28$ & 0.17 & 6.1 & 16.3 & 0.2 & 0.4 & 0 & 0 & 16.9 & 0 & 0.16 & 96.9 & 1.7 & 1.4 & & 0.000 & 0.00 \\
\hline $\mathrm{Db}$ & $28-30$ & 1.93 & 5.8 & 219 & 0.7 & 1 & 0.1 & 1.8 & 209 & 10.1 & 0.14 & 97.2 & 2 & 0.8 & & 0.009 & 0.18 \\
\hline Bwb & $30-52$ & 4 & 6 & 415 & 1.1 & 1.5 & 0.1 & 88.3 & 414 & 0 & 0.27 & 84.1 & 4 & 11.9 & & 0.213 & \\
\hline $\mathrm{BCb}$ & $52-65$ & 2.96 & 5.8 & 305 & 1 & 1.3 & 0.1 & 2.7 & 294 & 10.3 & 0.27 & 76.7 & 12 & 11.8 & & 0.009 & 0.26 \\
\hline $\mathrm{Cb}$ & $65-100$ & 1.68 & 5.9 & 172 & 0.6 & 0.9 & 0.1 & 1.4 & 167 & 5.5 & 0.19 & 83.9 & 4.8 & 11.3 & & 0.008 & 0.25 \\
\hline \multicolumn{18}{|c|}{ 77-28 Typic Anhyorthels; upper Lake Vanda shoreline; Wright Valley } \\
\hline Cox & $0.5-20$ & 2.4 & 7.8 & 12.0 & 10.0 & 2.7 & 0.5 & 22.0 & 1.9 & 0.64 & & & & & & 11.6 & 34.4 \\
\hline $2 \mathrm{Bwb}$ & $20-40$ & 5.1 & 7.7 & 34.0 & 16.0 & 6.2 & 0.9 & 54.0 & 2.2 & 0.85 & & & & & & 24.5 & 63.5 \\
\hline $2 \mathrm{Cnb}$ & $40-65$ & 2.6 & 7.6 & 15.0 & 7.8 & 2.4 & 0.6 & 22.0 & 2.8 & 0.64 & & & & & & 7.9 & 34.4 \\
\hline \multicolumn{18}{|c|}{ 79-08 Typic Haploturbels; undifferentiated drift; Labyrinth, Wright Valley } \\
\hline $\mathrm{Bw}$ & $0.5-13$ & 2.9 & 6.9 & 23.0 & 1.6 & 8.5 & 0.2 & 17.0 & 7.2 & 7.6 & & & & & & 2.4 & 2.2 \\
\hline $\mathrm{Cn}$ & $13-29$ & 0.83 & 7.0 & 7.8 & 0.1 & 0.5 & 0.1 & 4.9 & 1.0 & 2 & & & & & & 5.1 & 2.5 \\
\hline $\mathrm{Cf}$ & $29-37$ & 0.63 & 7.1 & 5.1 & 0.1 & 0.3 & 0.1 & 2.9 & 1.2 & 1.1 & & & & & & 2.4 & 2.6 \\
\hline \multicolumn{18}{|c|}{ 83-41 Petrosalic Anhyorthels; ripples/Alpine 3b/Peleus; Conrow Glacier, Wright Valley } \\
\hline $\mathrm{Cn}$ & $0-14$ & 5.3 & 7.3 & 47.3 & 13 & 1.6 & 0.6 & 32.4 & 18.8 & 1.67 & & & & & 0.9 & 1.7 & 19.4 \\
\hline $2 \mathrm{Bwzb}$ & $14-28$ & 80 & 7.8 & 1089 & 36.9 & 111 & 2.6 & 748 & 227 & 77.0 & & & & & 3.74 & 3.3 & 9.7 \\
\hline $2 \mathrm{Bwb}$ & $28-70$ & 9.3 & 7.1 & 100.4 & 14.2 & 10.1 & 1 & 78.1 & 28.3 & 1.79 & & & & & 0.69 & 2.8 & 43.6 \\
\hline $3 \mathrm{Bwb}$ & $70-120$ & 3.6 & 6.4 & 16.2 & 9.3 & 13.5 & 1.6 & 17 & 17.3 & 1.59 & & & & & 1.41 & 0.98 & 10.7 \\
\hline \multicolumn{18}{|c|}{ 84-47 Petrosalic Anhyorthels; Alpine 3b; Meserve Glacier, Wright Valley } \\
\hline Bw1 & $0-4$ & 4.8 & 7.0 & 21.9 & 34.4 & 7.6 & 1.1 & 18.2 & 45.9 & 3.64 & & & & & 1 & 0.40 & 5.0 \\
\hline Bwz1 & $4-20$ & 80 & 7.1 & 820.4 & 16.1 & 83.7 & 7.5 & 948 & 157.6 & 23.6 & & & & & 2.04 & 6.0 & 40.1 \\
\hline Bwz2 & $20-42$ & 31 & 6.9 & 302.2 & 6.4 & 55.0 & 6.6 & 269 & 50.4 & 20.1 & & & & & 1.42 & 5.3 & 13.4 \\
\hline Bw2 & $42-85$ & 4.4 & 6.7 & 30.3 & 2.3 & 7.4 & 2.7 & 30.6 & 7.7 & 4.75 & & & & & 0.75 & 4.0 & 6.4 \\
\hline \multicolumn{18}{|c|}{ 84-49 Salic Anhyorthels; Alpine 3/Peleus; Bartley Glacier, Wright Valley } \\
\hline $\mathrm{Bw}$ & $0-4$ & 5.6 & 7.4 & 28.0 & 34.8 & 5.1 & 1.5 & 26.8 & 44.5 & 0.56 & & & & & 1.21 & 0.60 & 47.9 \\
\hline Bwz & $4-33$ & 18 & 6.2 & 198 & 35.9 & 15.9 & 3.3 & 225 & 34.4 & 11.5 & & & & & 0.86 & 6.5 & 19.5 \\
\hline $\mathrm{BC}$ & $33-61$ & 6.5 & 7.0 & 54.2 & 9.9 & 17.0 & 2.9 & 64.4 & 10.0 & 8.5 & & & & & 1.05 & 6.4 & 7.6 \\
\hline $2 \mathrm{Bwb}$ & 61-99 & 11.8 & 7.2 & 77.6 & 19.8 & 53.1 & 4.1 & 13.2 & 7.9 & 26.3 & & & & & 5.36 & 1.7 & 0.50 \\
\hline $3 \mathrm{Bwb}$ & 99-115 & 5.5 & 7.7 & 27.4 & 7.3 & 29.2 & 1.5 & 45.0 & 0.6 & 0.76 & & & & & 3.95 & 78.9 & 59.2 \\
\hline Peleus pan & $115+$ & 75 & 7.8 & 1168 & 41.9 & 31.1 & 15.9 & 900 & 38.5 & 319 & & & & & 1.75 & 23.4 & 2.82 \\
\hline \multicolumn{18}{|c|}{ 78-33 Typic Anhyorthels; undifferentiated drift; Darwin Mountains } \\
\hline $\mathrm{Bw}$ & $0.5-7$ & 2.8 & 6.1 & 11 & 13 & 11 & 0.49 & 2.4 & 18 & 13 & & & & & & 0.13 & 0.18 \\
\hline $\mathrm{BC}$ & $7-15$ & 1.3 & 6.9 & 7.3 & 0.59 & 6.3 & 0.4 & 2.3 & 1.8 & 8.6 & & & & & & 1.28 & 0.27 \\
\hline $\mathrm{Cn}$ & $15-26$ & 2.1 & 6.8 & 10 & 3.8 & 11 & 0.56 & 2.7 & 6.4 & 13 & & & & & & 0.42 & 0.21 \\
\hline $2 \mathrm{Db}$ & $26-30$ & & & & & & & & & & & & & & & & \\
\hline 2Bwb1 & $30-41$ & 1.6 & 5.3 & 6.7 & 4 & 7 & 0.3 & 2.4 & 7.9 & 8.1 & & & & & & 0.30 & 0.30 \\
\hline 2Bwb2 & $41-53$ & 1.1 & 6.9 & 6.5 & 0.16 & 3.8 & 0.21 & 2.5 & 0.8 & 8.1 & & & & & & 3.13 & 0.31 \\
\hline
\end{tabular}

The surficial geology map of central Wright Valley (Hall and Denton, 2005) was used to delineate areas of relict, buried, and modern soils. Approximately $55 \%$ of the soils are relict and approximately $10 \%$ of the area contains buried soils (map not shown).

\section{Discussion}

\subsection{Cold-based glaciers}

The abundance of relict and buried soils in the TAMs may be attributed to the activity of cold-based glaciers (Bockheim, 2010b). Cold-based glaciers are able to drop boulderbelt moraines and isolated boulders over minimally disturbed landscapes. When observed in vertically, the boulder belts in some cases are separated by drift of the same age; in other cases the boulder belts overlie older drift (Bockheim, 1982).

Buried soils and recycled ventifacts are found in drifts ranging from the Last Glacial Maximum to Miocene (>15 Ma) in age. They are especially prevalent in drifts from dry-based portions of outlet glaciers, which tend to be thin, ranging from $<1$ to about $5 \mathrm{~m}$ in thickness. With each subsequent glacial advance, the drift with its soil mantle is either overridden by a dry-based glacier or is incorporated into the most recent drift. For this reason, a young drift may contain clasts that range from fresh to highly weathered. Boulders with fresh striations etched into a strongly developed desert varnish are commonly observed in the TAMs. Similarly, clasts occurring at the base of alpine glaciers reveal previous weathering cycles. For example, we have observed fragile weathering features such as cavernously weathered boulders 
entrained within dry-based glaciers. This phenomenon may lead to problems when cosmogenically dating boulders that are spatially in-between boulder-belt moraines (Bockheim, 2010b).

\subsection{Environmental implications}

The soils of Antarctica preserve a climate and geologic record of when Antarctica was part of Gondwana, the gradual isolation of the continent, the buildup of a continental ice sheet, and the conversion from warm-based glaciers to coldbased glaciers, culminating in the development of hyper-arid, polar conditions. The continental ice sheet developed during 40-34 Ma as Gondwana broke up and Antarctica became isolated.

From ca. 19-14.8 Ma the polar regolith formed (Sugden and Denton, 2004). Cold-based glaciers overrode the TAMs during 14.8-13.6 Ma, creating dramatic scabland topography with drainage basins, channels, plunge pools, and giant potholes. Relict soils remain in several areas. These soils tend to be thin and support highly weathered dolerite clasts. Beginning in $13.6 \mathrm{Ma}$, hyper-arid, polar conditions formed in the TAMs. Soils contain abundant salts; ice wedges on Miocene through early Pleistocene surfaces have sublimated, leaving thermokarst topography; permafrost tends to be dry-frozen; desiccation cracks become common in the soils; strongly developed desert pavements underlain by a vesicular layer are formed, and mega-ripples from strong katabatic winds become prevalent. During this period the TAMs become one of the driest places on Earth. Anion ratios can be used to show changes in air masses and contribution of salts from marine aerosols during these climate changes. Pedon 84-49 has had greater proportions of $\mathrm{SO}_{4}$ and $\mathrm{NO}_{3}$ relative to $\mathrm{Cl}$ during the Quaternary than during the Pliocene when the Wright Valley was a fjord (Table 4; see also Prentice and Krusic, 2005).

The Anthropocene is an informal geologic chronological term that serves to mark the evidence and extent of human activities that have had a significant global impact on the Earth's ecosystems. The TAMs have not been immune to the consequences of a warming climate. A recent report identifies the southern TAMs as among the most rapidly warming regions on Earth (Bromwich et al., 2013). Historical observations by the author include melting of semi-permanent snowbanks, yielding nivation hollows with permafrost closer to the surface than in adjoining areas, flushing of salts from soils along valley walls, the development of hyporheic zones distant from water bodies from melting of snow in highelevation catchments that flows downslope above the icecemented permafrost table, and milder summer temperatures accompanied by rising lake levels and periodic flooding of the Onyx River in Wright Valley. As the climate continues to warm in the TAMs, dramatic changes in the permafrost regime, thickness of the seasonal thaw layer, geomorphic processes, and soil development can be expected.

\section{Conclusions}

Relict soils constitute $73 \%$ of all of the 800 pedons examined in the Transantarctic Mountains (TAMs); $10 \%$ of the soils featured burials. About $26 \%$ of the soils examined are from the last glaciation $(<117 \mathrm{ka})$ and have not undergone any apparent change in climate. In central Wright Valley, where detailed surficial geology and soil maps are available, paleosols comprise $65 \%$ of the ice-free area.

The preservation of paleosols in the TAMs can be attributed to cold-based glaciers that are able to override landscapes while causing minimal disturbance. Paleosols illustrate the dramatic changes in climate that have occurred in Antarctica, particularly during the mid-Miocene when the climate shifted from cool temperate to hyper-arid and during the Anthropocene when rapid warming is increasing the availability of liquid water and causing leaching of salts from the soils.

Acknowledgements. The author appreciates the field assistance of G. H. Denton, S. C. Wilson, M. McLeod, and many students. This work was supported by the US National Science Foundation, Office of Polar Programs, Antarctic Sciences, and the New Zealand Ministry of Science and Innovation.

Edited by: A. Navas

\section{References}

Ackert Jr., R. P. and Kurz, M. D.: Age and uplift rates of Sirius Group sediments in the Dominion Range, Antarctica, from surface exposure dating and geomorphology, Global Planet. Change, 42, 207-225, 2004.

American Public Health Association, American Water Works Association, Water Pollution Control Federation: Standard Methods for the Examination of Water and Wastewater, 14th Edn., 1193 pp., 1975.

Bockheim, J. G.: Properties of a chronosequence of ultraxerous soils in the Trans-Antarctic Mountains, Geoderma, 28, 239-255, 1982.

Bockheim, J. G.: Soil development rates in the Transantarctic Mountains, Geoderma, 47, 59-77, 1990.

Bockheim, J. G.: Soil processes and development rates in the Quartermain Mountains, upper Taylor Glacier region, Antarctica, Geogr. Ann. A, 89, 153-165, 2007.

Bockheim, J. G.: Evolution of desert pavements and the vesicular layer in soils of the Transantarctic Mountains, Geomorphology, 118, 433-443, 2010a.

Bockheim, J. G.: Soil preservation and ventifact recycling from dry based glaciers in Antarctica, Antarctic Science, 22, 409-417, 2010b.

Bockheim, J. G. and McLeod, M.: Glacial geomorphology of the Victoria Valley System, Ross Sea Region, Antarctica, Geomorphology, 193, 14-24, 2013.

Bockheim, J. G., Wilson, S. C., Denton, G. H., Andersen, B. G., and Stuiver, M.: Late Quaternary ice-surface fluctuations of Hather- 
ton Glacier, Transantarctic Mountains, Quaternary Res., 31, 229254, 1989.

Bronger, A. and Catt, J. A. (Eds.): Paleosols Problems of definition, recognition, and interpretation, in: Nature and Application of Paleosols, Catena Supplement, 16, 1-7, 1989.

Bromwich, D. H., Nicolas, J. P., Monaghan, A. J., Lazzara, M. A., Keller, L. M., Weidner, G. A., and Wilson, A. B.: Central West Antarctica among the most rapidly warming regions on Earth, Nat. Geosci., 6, 139-145, doi:10.1038/NGEO1671, 2013.

Brook, E. J., Kurz, M. D., Ackert Jr., R. P., Denton, G. H., Brown, E. T., Raisbeck, G. M., and Yiou, F.: Chronology of Taylor Glacier advances in Arena Valley, Antarctica, using in situ cosmogenic ${ }^{3} \mathrm{He}$ and ${ }^{10} \mathrm{Be}$, Quaternary Res., 39, 11-23, 1993.

Calkin, P. E.: Glacial geology of the Victoria Valley system, southern Victoria Land, Antarctica, in: Antarctic Snow and Ice Studies II, edited by: Crary, A. P., American Geophysical Union, Washington DC, Antarctic Research Series, 16, 363-412, 1971.

Campbell, I. B. and Claridge, G. G. C.: Antarctica: Soils, Weathering Processes and Environment, Elsevier, New York, 1987.

Day, P. R.: Particle fractionation and particle-size analysis, in: Methods of Soil Analysis, edited by: Black, C. A., Evans, D. D, White, J. L., Ensminger, L. E., and Clark, F. E., American Society of Agronomy, Agronomy, Number 9, Part 1, 545-567, 1965.

Denton, G. H., Bockheim, J. G., Wilson, S. C., Leide, J. E., and Andersen, B. G.: Late Quaternary ice-surface fluctuations of Beardmore Glacier, Transantarctic Mountains, Quaternary Res., 31, 183-209, 1989.

Gillies, J. A., Nickling, W. G., Tilson, M., and Furtak-Cole, E.: Wind-formed gravel bed forms, Wright Valley, Antarctica, J. Geophys. Res., 117, FO4017, doi:10.1029/2012JF002378, 2012.

Hall, B. L. and Denton, G. H.: Surficial geology and geomorphology of eastern and central Wright Valley, Antarctica, Geomorphology, 64, 25-65, 2005.

Hall, B. L., Denton, G. H., Lux, D. R., and Bockheim, J. G.: Late Tertiary Antarctic paleoclimate and ice-sheet dynamics inferred from surficial deposits in Wright Valley, Geogr. Ann. A, 75, 238267, 1993.

Higgins, S. M., Hendy, C. H., and Denton, G. H.: Geochronology of Bonney drift, Taylor Valley, Antarctica: evidence for interglacial expansions of Taylor Glacier, Geogr. Ann. A, 82, 391-410, 2000.

Mahaney, W. C., Dohm, J. M., Baker, V. R., Newsom, H. E., Malloch, D., Hancock, R. G. V., Campbell, I., Sheppard, D., and Milner, M. W.: Morphogenesis of Antarctic paleosols: Martian analogue, Icarus, 154, 113-130, 2001.

Mahaney, W. C., Hart, K. M., O'Reilly, S. S., Allen, C. C. R., Dohm, J. M., Hancock, R. G. V., Kelleher, B. P., and Milner, M. W.: Coleoptera and microbe biomass in Antarctic Dry Valley paleosols adjacent to the Inland Ice: Implications for Mars, Planet. Space Sci., 60, 386-398, 2012.

Marchant, D. R. and Head III, J. W. : Antarctic dry valleys: microclimate zonation, variable geomorphic processes, and implications for assessing climate change on Mars, Icarus, 192, 187222, 2007.
Marchant, D. R., Denton, G. H., and Swisher, C. C.: MiocenePliocene Pleistocene glacial history of Arena Valley, Quartermain Mountains, Antarctica, Geogr. Ann. A, 75, 269-302, 1993a.

Marchant, D. R., Denton, G. H., Sugden, D. E., and Swisher III, C. C.: Miocene glacial stratigraphy and landscape evolution of the western Asgard Range, Antarctica, Geogr. Ann. A, 75, 303-330, $1993 b$.

Marchant, D. R., Denton, G. H., Bockheim, J. G., Wilson, S. C., and Kerr, A. R.: Quaternary changes in level of the upper Taylor Glacier, Antarctica: implications for paleoclimate and East Antarctic ice sheet dynamics, Boreas, 23, 29-43, 1994.

Mehra, O. P. and Jackson, M. L: Iron oxide removal from soils and clays by a dithionite-citrate system buffered with sodium bicarbonate, Clays and Clay Minerals, 7, 317-27, 1960.

Mercer, J. H.: Glacial geology of the Reedy Glacier area, Antarctica, Geol. Soc. Am. Bull., 79, 471-486, 1968.

Nettleton, W. D., Olson, C. G., and Wysocki, D. A.: Paleosol classification: problems and solutions, Catena, 41, 61-92, 2000.

Prentice, M. L. and Krusic, A. G.: Early Pliocene alpine glaciation in Antarctica: terrestrial versus tidewater glaciers in Wright Valley, Geogr. Ann. A, 87, 87-109, 2005.

Prentice, M. L., Denton, G. H., Bockheim, J. G., Wilson, S. C., Burckle, L. H., Hodell, D. A., and Kellogg, D. E.: Late Neogene glacial history: evidence from central Wright Valley, in: The Antarctic paleoenvironment: a perspective on global change, edited by: Kennett, J. and Warnke, D., American Geophysical Union, Antarctic Res. Ser., 60, 207-250, 1993.

Retallack, G. J. and Alonso-Zarza, A. M.: Middle Triassic paleosols and paleoclimate of Antarctica, J. Sediment. Res., 68, 169-184, 1998.

Retallack, G. J., Krull, E. S., and Bockheim, J. G.: New grounds for reassessing paleoclimate of the Sirius Group, J. Geol. Soc. Lond., 158, 925-935, 2002.

Ruhe, R. V.: Quaternary paleopedology, in: The Quaternary of the United States, edited by: Wright, H. E. and Frey, D. G., Princeton University Press, Princeton, NJ, 755-764, 1965.

Schoeneberger, P. J., Wysocki, D. A., Benham, E. C., and Broderson, W. D.: Field book for describing and sampling soils (V. 2), Natural Resources Conservation Service, USDA, National Soil Survey Center, Lincoln, Nebraska, 2002.

Soil Survey Staff: Keys to Soil Taxonomy (11th Edn.), USDA, National Resources Conservation Service, National Soil Survey Center, Lincoln, NE, 2012.

Sugden, D. E. and Denton, G. H.: Cenozoic landscape evolution of the Convoy Range to Mackay Glacier area, Transantarctic Mountains: Onshore to offshore synthesis, Geol. Soc. Am. Bull., 116, 840-857, 2004.

Wilch, T. I., Denton, G. H., Lux, D. R., and McIntosh, W. C.: Limited Pliocene glacier extent and surface uplift in middle Taylor Valley, Antarctica, Geogr. Ann. A, 75, 331-351, 1993. 